- Indian academic salaries are not globally competitive, even taking into account variations in living costs. Senior academics at US research universities typically earn $\$ 130,000$ and up annually, and those at top US universities can earn $\$ 200,000$ or more. The average salaries for full-time academics is $\$ 73,000$, with those in high demand fields in the sciences, business, and others earning significantly more. In comparison, Indian salaries in the IITs, according to the latest Pay Commission recommendations, starts at $\$ 17,622$ for assistant professors, rising to around $\$ 38, \mathrm{I} 65$ for full professors. Higher ranks earn somewhat more. China, which is also actively luring top international faculty to its research universities, offers salaries of \$100,000 or more, along with additional research funding.

- Indian public institutions have little experience in hiring international faculty and much experience with stifling bureaucracy. This means that processing academic appointments for foreign faculty is quite time-consuming, as approval by multiple government departments is needed in addition to standard university procedures. Indian public universities do not have processes in place to handle such appointments.

- International faculty cannot be offered long-term appointments in Indian public institutions. Fiveyear contracts are all that is available-although these may be extended. Thus, there is little job security.

- Obtaining research funding is difficult and the resources available, by international standards, are quite limited. The bureaucratic procedures relating to research grants are also daunting. This is in sharp contrast to China, where significant research funding is offered almost automatically to foreign faculty.

- Few IITs have considered foreign hiring as an important part of their academic initiatives. Premier institutions such as IIT Bombay now provides foreign faculty around \$I,500 as relocation allowance. Although a seed grant of up to $\$ 29,000$ is provided to new international faculty members to meet the initial cost for setting up a research laboratory, only around $\$ 2,900$ is provided as a Cumulative Professional Development Allowance (CPDA) every three years for presenting papers at conferences. In addition, political and security clearance from the ministries of external affairs and home affairs are necessary in every case for individuals with foreign passports.

\section{Different Strategies}

On the other hand, a few "elite" nonprofit private universities such as O.P. Jindal, Azim Premji, Ashoka, Shiv Nadar, Ahmedabad, Krea, and the Indian School of Business have adopted different strategies, attracting foreign nationals and Indians who have studied at prestigious foreign universities by offering higher salaries and other benefits that are not available to local hires. The faculty diversity of O.P. Jindal Global University, which is located in the national capital region of Delhi, stands out with 7I full-time foreign faculty originating from 32 countries. The key motivation for hiring foreign faculty at all these institutions, mainly in liberal arts and professional courses such as engineering, management, and law, is to improve international competitiveness and secure positions in global rankings, which in turn should also attract more motivated students.

The measures taken by these new private universities with, by Indian standards, considerable resources have proved that it is possible to attract foreign faculty, at least those with an Indian ethnic background. But the challenges faced by public institutions, even those as high quality as the IITs and the best universities, seem insurmountable, at least in the context of the current Indian higher education environment and bureaucratic and legal framework.

\section{Indian Research Universities and Global Rankings}

\section{Pankaj Jalote}

Pankaj Jalote is distinguished professor and founding director, IIIT-Delhi, India.E-mail: jalote@iiitd.ac.in.

A more detailed report is available on the website of Current Science, May 2019 issue.

$\mathrm{T}$ his century has seen a dramatic rise in the importance of global university rankings. In India, as in many other countries, there is a strong desire to have some of the nationally preeminent universities recognized among the best in the world. Currently, there are no Indian universities in the top 200 of the Academic Rankings of World Universities (ARWU, or "Shanghai ranking"), the Times Higher Edu- 
cation (THE) rankings, or the QS rankings.

Global rankings largely depend on the research performance of a university, in particular on factors like publications, citations, $\mathrm{PhD}$ programs, and research income. Only top research institutions at the national level can hope to make it to the top 200. To find out whether some of the best research universities in India can make it to this group, we must identify the key characteristics of top global universities and understand how top Indian universities compare. (In India, top institutions include, in particular, the Indian Institutes of Technology [IITs], the Institute of Science, Jawaharlal Nehru University, Banaras Hindu University, and Jadavpur University. Specialized institutions in fields such as law, pharmacy, and management, would not be eligible.) When looking at the top 200 universities globally in the THE ranking and at the top roo universities and engineering institutes in the new Indian national ranking (NIRF), three critical factors appear for both groups: age, size, and funding.

\section{Age}

In THE rankings, the distribution of top institutions along different time periods is as follows: 135 were created in the nineteenth century when the Humboldtian model of research universities was spreading rapidly; 30 were created in the first half of the twentieth century; and only 38 were created after I950, of which only I5 were founded after I 975 .

In India, among the best institutions, only six were created before I900, and only I7 were created in the first half of the twentieth century. In the quarter century after independence (between I950 to I975), 58 were established, including the five original IITs. The vast majority-II9 in total—were created after I975. In other words, whereas only 7 percent of the world's top universities were created after I975, in India this is the case for about 60 percent; and while 65 percent of the world's top universities were created before I900, only 3 percent of India's universities were established that early.

\section{SIZE}

In terms of size, among top universities worldwide, over 90 percent have more than I0,000 students (over 6o percent have actually more than 20,000 students), and only about 2 percent have a student population of less than 5,000. In terms of faculty size, only 6 percent have less than 500 , while about 70 percent have more than I,०००. In India, on the other hand, only seven engineering institutions and 23 universities have more than I0,000 students, while about 60 percent have less than 5,000 . In terms of faculty size, only four have more than $\mathrm{I}, 000$, while over 80 percent have less than 500 .
Large size leads to wider research scope and contributions, as well as interdisciplinary research. A large faculty body will also lead to more research, which increases the chances of high impact research. And a larger student population graduating each year implies that their contribution, impact, and influence on society are more significant.

\section{FUNDING}

With talented research faculty who have to be well compensated, research universities are costly to run. In support of their research, expensive research labs, high quality computing infrastructure, libraries, PhD students, travel support for conferences, etc. have to be provided, further increasing the overall expenditure per faculty. The average expenditure per faculty in universities ranked between 150 to 200 in THE-which is realistically the range that Indian universities can target-is about US\$0.5 million. The average R\&D expenditure per faculty in US research universities with moderate research activity, according to the Carnegie classification of 2015 , is about US $\$ 32,000$. (For universities with the highest research activity, the $R \& D$ expenditure is about US\$294,000).

\section{The composition of the student body at private providers is distinct from the public sector in several respects.}

In India, the expenditure per faculty in institutions at a corresponding level is less than US\$0.05 million, and the research grant per faculty is about US\$5,000. Even when considering the fact that manpower and some other costs are lower in India (though research equipment, international travel, digital library subscriptions, etc. cost the same as in other countries), this level of expenditure and $R \& D$ investment is significantly lower than in universities ranked I50-200 in THE, or at research universities in the moderate research activity category in the United States. For India's top higher education institutions to reach world rankings, investments in research will have to increase substantially.

\section{CONCLUSION}

The age, size, and funding profile of top Indian institutions is significantly different from that of the top global 200 universities. While nothing can be done about age, size and funding can be increased.

In order to expand the higher education system, the approach taken by India is to create new institutions, some- 
times at a hectic pace. To be listed among top global universities, premier Indian institutions should receive support to become multidisciplinary and increase their number of faculty. If faculty at 50 research institutions (e.g., IITs and central universities) can be increased to more than I,000, this could have an impact on global rankings. In addition, India could experiment with creating a few megainstitutions by merging existing universities, colleges, and research labsan approach Australia took a few decades ago with remarkable success, and also pursued in France.

To enter world rankings, support for research will have to increase substantially. For this, two initiatives can help. First, top institutions could be provided with committed, multiyear research funding based on past performancean approach that Australia and the United Kingdom follow with great results. Second, research project funding by agencies needs to increase dramatically and be accessible to all research universities - whether private or government. Many advanced countries invest over 20 percent of their public R\&D expenditure in the university sector. In India, less than 4 percent of the government $R \& D$ expenditure goes to universities. The distribution of R\&D funding must progressively move toward more support for research in universities.

It must be emphasized that sufficient size and funding alone will not automatically ensure a position in global rankings. In addition, universities in the top league will need to have strong systems to encourage and support high quality research, recruit the best talent and promote meritocracy, build a vibrant innovation culture, have strong leadership and governance, etc.

It should also be kept in mind that being in the top 200 globally is a zero-sum game. For an Indian institution to be in this group, a university currently at the top will have to drop out. As many countries currently are eager to be represented among this elite group, competition is every year getting tougher, and changes need to happen at a faster pace.

In cooperation with the American Council on Education, CIHE has published International Briefs for Higher Education Leaders no. 8 on Attainment and Inclusion in Higher Education. This annual brief was edited by Robin Matross Helms and Lucia Brajkovic from ACE and Laura E. Rumbley from the European Association for International Education, and contains I3 international perspectives and four case studies from different countries around the globe. It examines sustained efforts undertaken to ensure equitable opportunities for degree attainment for all students, including underserved or traditionally marginalized populations.

\section{Concentration of Institutions and Urban Bias in India}

\section{N.V. Varghese and Jinusha Panigrahi}

N.V. Varghese is vice-chancellor and director of the Center for Policy Research in Higher Education, National Institute of Educational Planning and Administration (CPRHE/NIEPA), New Delhi, India. E-mail: nv.varghese@niepa.ac.in. Jinusha Panigrahi is assistant professor at CPRHE/NIEPA. E-mail: jinusha@niepa.ac.in.

$\mathrm{T}$ The massification of higher education is in general associated with improved access and reduced inequalities. Empirical evidence in India shows that the expansion of the system is accompanied by various forms of inequalities. Traditionally, the higher education sector in India has grown slowly, with low enrollment rates. This century witnessed a dramatic turnaround when the sector experienced accelerated growth leading to the massification of the sector. In 20I7-20I8, India had more than 900 universities, 4I, 000 colleges, 36.6 million students, and a gross enrollment ratio (GER) of 25.8 percent. Regional inequalities in higher education development have widened and social inequalities continue to be high, while gender inequalities are narrowing down. Based on a study conducted by the Centre for Policy Research in Higher Education at the National Institute of Educational Planning and Administration (CPRHE/ NIEPA), this article discusses some important features of concentration and urban bias in higher education development in India. This is relevant for higher education policy in this country and in other countries around the world with similar issues.

\section{Urban Bias in Higher Education Development}

Any economic growth process produces concentration and diffusion effects. Concentration effects through unequal resource allocations lead to regional polarization. Diffusion effects, through their forward and backward linkages, result in spread development. Since knowledge economies rely on universities for knowledge production and the training of knowledge workers, a dispersed growth of universities help develop research capacities to support faster growth and a balanced regional development.

As in many countries, the development of higher education in India has an urban bias. The first group of universities were established in 1857 in the Presidencies (cities) of Calcutta, Bombay, and Madras. The establishment of higher education institutions (HEIs) in the postindependence period also favored urban locations. The universities and HEIs established in the I950s and I960s were mostly in 